\title{
EVALUATION OF COASTLINE DEVELOPMENT OVER PERIODS IN CUA VIET AREA BY APPLICATION OF REMOTE SENSING TECHNIQUE AND GEOGRAPHIC INFORMATION SYSTEM (GIS)
}

\author{
Dao Dinh Cham*, Nguyen Thai Son \\ Institute of Geography-VAST \\ "E-mail: chamvdl@gmail.com
}

Received: 7-1-2016

\begin{abstract}
The development of the coastline in Cua Viet outlet area from 1952 to 2015 was quantitatively evaluated using remote sensing technique and geographic information system (GIS). The result of the research shows that in the Cua Viet outlet area the accretion and erosion phenomena occur in a very complex manner, with erosion predominating over accretion in both scale and intensity, in which the coast sections with the largest scale and highest intensity of erosion are usually located near the outlet (both inside and outside the outlet). In the coast section inside the outlet, the erosion on the northern side occurs more intensively than on the southern side, with the erosion rate reaching -1.51 to $-2.24 \mathrm{~m} /$ year, whereas the accretion rate is 1.15 to $1.70 \mathrm{~m} / \mathrm{year}$. The ratio between the erosional and accretional rates is 1.0 to 1.5 times. In the coast section outside the outlet, erosion occurs much more intensively, with its rate from - 2.74 to $-8.18 \mathrm{~m} /$ year, whereas the accretion rate is only 0.12 to $2.41 \mathrm{~m} / \mathrm{year}$. The ratio between the erosion and accretion is 1.0 to 38 times. Recently, the newly-built Cua Viet seawall has partially reduced the process of coastal erosion, the beach starts to consolidate in the foot area.
\end{abstract}

Keywords: Remote sensing technique, GIS, coastline, outlet area, Cua Viet.

\section{INTRODUCTION}

The coastal area of Quang Tri province frequently suffers severe natural hazards such as typhoon, flood, inundation, coastal and river bank erosion-accretion, sedimentation and migration of outlet channels ... Quang Tri province has a $75 \mathrm{~km}$ long coastline with over $60 \mathrm{~km}$ of unconsolidated sediments. Due to this together with other natural processes, erosion and accretion are occurring with ever increasing magnitude and intensity. In Cua Viet outlet area, coastal collapse frequently occurs. In recent years 2002, 2003, 2006, 2007 and 2009 , erosion has occurred rather intensively over a length of some hundreds of meters and with a rate of some tens of meters/year [1].
Together with erosion, sedimentation of the river mouth and harbor access channels takes place, causing difficulties to water transport, reducing the possibility of flood discharge and affecting other activities of the local people. The increasing erosion-accretion, shipping channel sedimentation hazards are threatening the socio-economic development and the life of the people in Quang Tri province in general and the Cua Viet outlet area in particular. So far, very few intensive research works have been carried out in this field in the estuarine and coastal areas of Quang Tri province. Only some general research projects have been carried out in the Central coastal zone or the whole coastal zone of our country. Some of these studies have referred to the environmental 
hazards such as flood, inundation, coastal and river bank erosion-accretion, ... in the coastal zone of Quang Tri but only qualitatively due to the limitation of the basic data on the estuarine and coastal area as well as that of the method of study. To evaluate quantitatively the development of the coastline and the outlet, it is necessary to use modern methods of study on dynamics of estuarine areas.

Within the context of this paper, the authors present the results of studies on the development of the coastline in the Cua Viet outlet area within the period from 1952 to 2015 by employing remote sensing and GIS methods.

\section{RESEARCH DATA AND METHOD}

\section{Research data}

Data source of maps and aerial photos was collected from previous studies of Pham Quang Son - Assessment of Thach Han river bed changes through the remote sensing data (1952-1999), satellilte images: http://www.glovis.usgs.gov/ and other related data: Nguyen Van $\mathrm{Cu}$ - Research on comprehensive measures for environmental protection and sedimentation control for flood discharge and clearing the access channel to Cua Viet and Dong Ha ports.

UTM topographic maps.

Air photos of 1952 (black and white): Taken and stored by the Cartographic Department of French Indochina. The photos are developed from the original negative films of $1: 33,000$ scale; the paper photos were scanned and digitized with resolution of 400 dpi (pixel/inc), then were subjected to geometric rectification based on the UTM topographic map of 1965.

Black and white air photos taken in 1979 (fig.2): Provided by the Land Administration Center of Information and Archive. The original photos are of 1:10,000 scale.

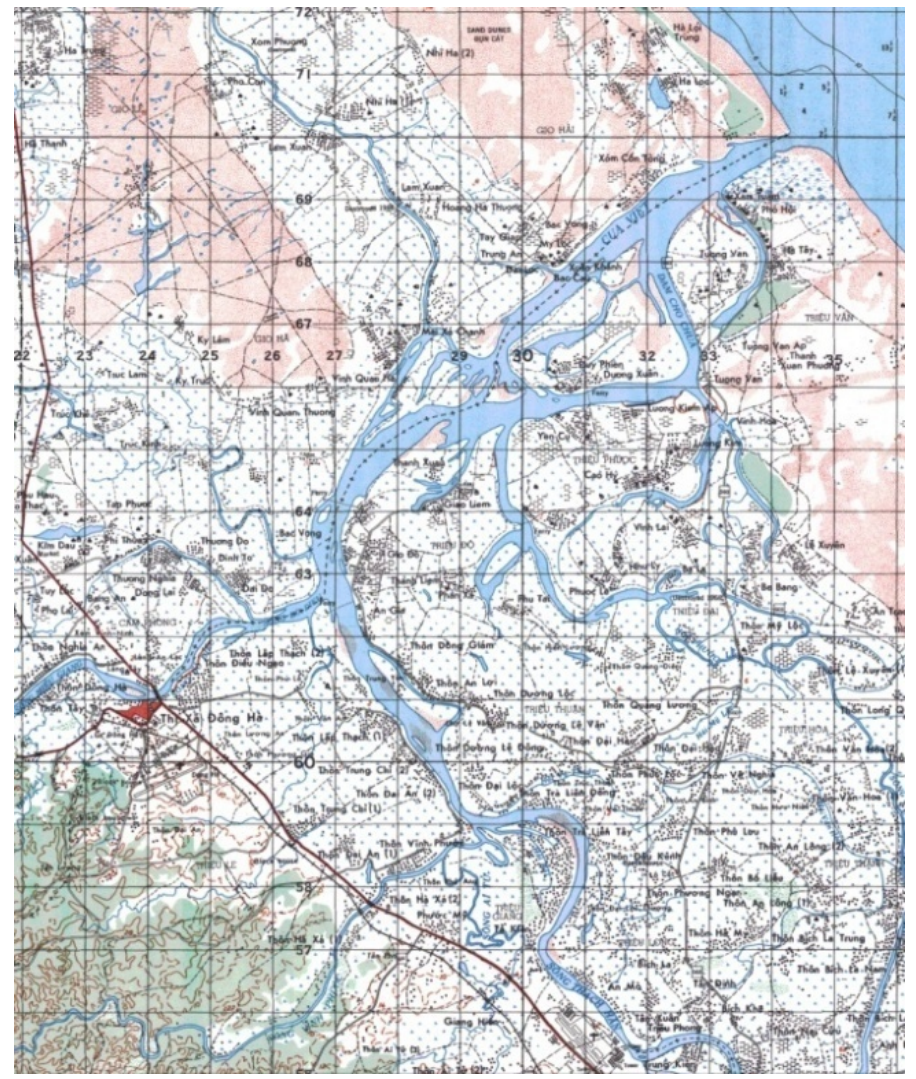

Fig. 1. UTM topographic map of the studied area published in 1965 


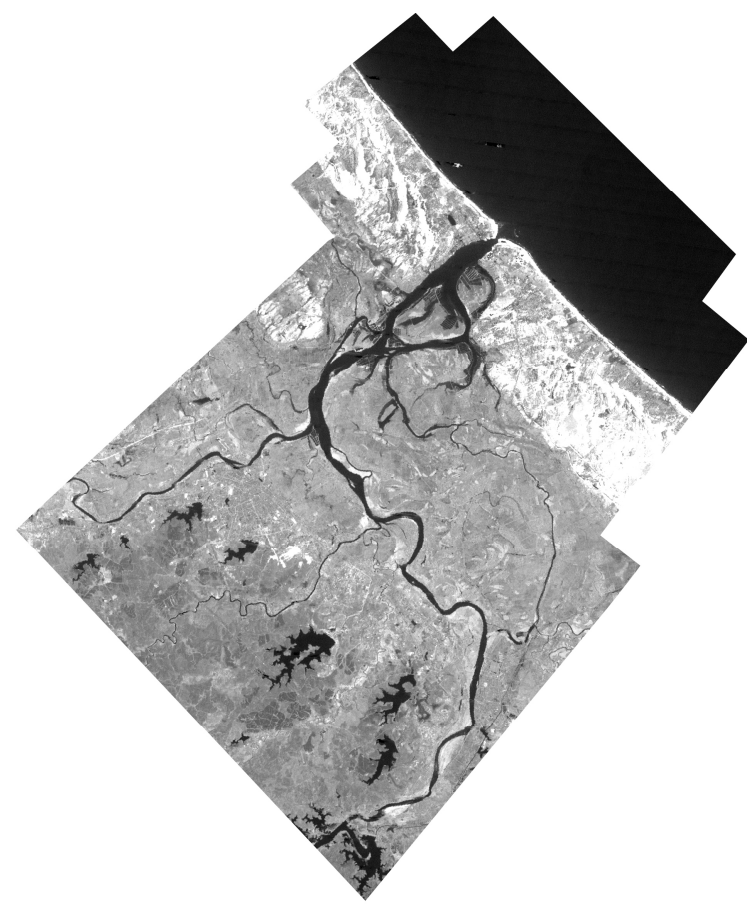

Fig. 2. Air photos of the studied area taken in May 1979

LANDSAT 5 TM satellite images, consisting of 7 bands, taken on 14 June 1990 (fig. 3).

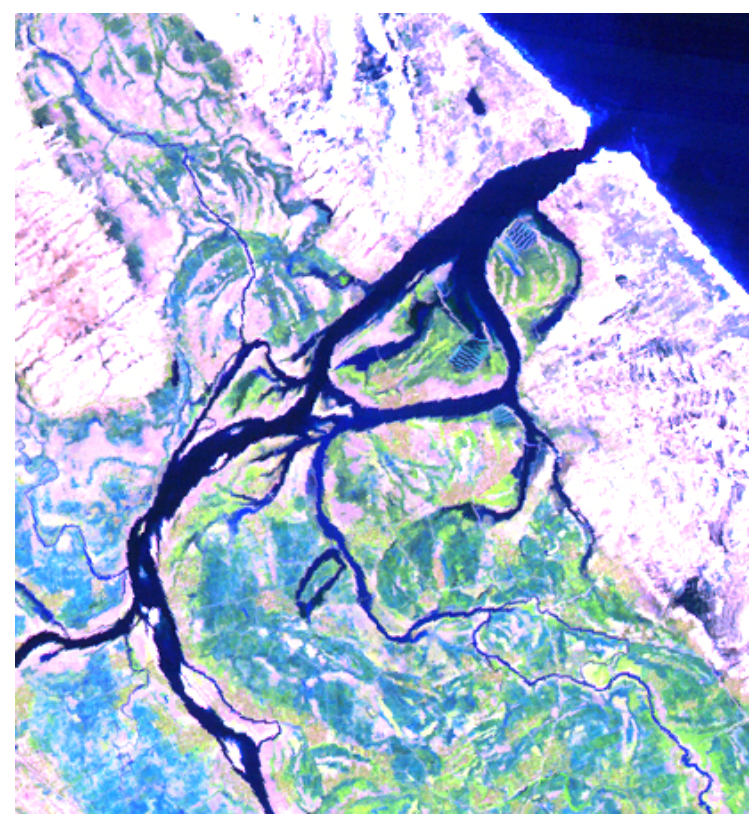

Fig. 3. Landsat TM satellite image of the studied area taken on 14 January 1990
LANDSAT 7 ETM satellite images, consisting of 7 bands, taken on 30 May 2000.

LANDSAT 7 ETM satellite images, consisting of 7 bands, taken on 23 March 2010.

LANDSAT 8 LGN satellite images, consisting of 11 bands, taken on 3 July 2015 (fig. 4).

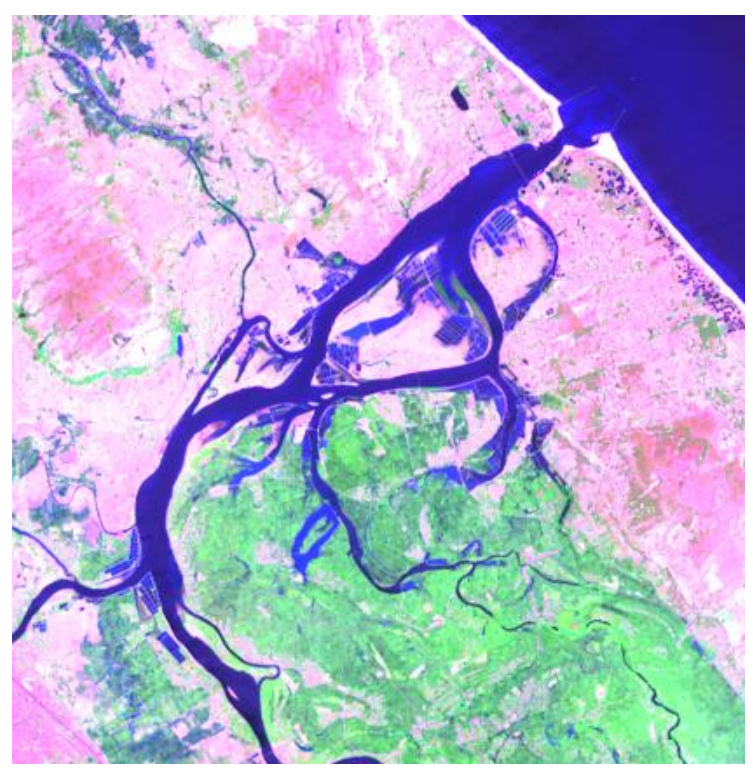

Fig. 4. Landsat 8 LGN satellite images, consisting of 11 bands, taken on 3 July 2015

The studied area is covered completely by the above photos and images. The LANDSAT satellite images have a spatial resolution of $15 \mathrm{~m}$ after being processed. Therefore, the above photos and images are acceptable for evaluating the changes of the channels and the coastline in the Cua Viet outlet area over periods of time.

\section{Other related data:}

This paper used data from topographic survey in Cua Viet outlet area in July 2006 and June 2007 to calibrate the processed results and interpolate the actual coastline. In the mean time, meteorological, hydrographic and oceanographic data were also used in combination for evaluating the impacts of tides and sea level on the river bank and coast, with the aim to ensure more precise results in the 
process of studying the changes of the coastline in Cua Viet outlet area.

In general the air photos and satellite images used for the research were taken in the dry season, so almost unaffected by clouds in the images. Besides, as the tidal fluctuation amplitude in the studied area is low $(0.5 \div$ $0.6 \mathrm{~m}$ ) [2], the determination of the coastline position on map and remote sensing data is acceptable [3].

\section{Method of research}

To evaluate quantitatively the development of the coastline in Cua Viet outlet area, remote sensing and GIS methods were employed in this study.

The essence of this method is the overlay of satellite images, air photos or maps of different points of time to determine the location of the river bank and coastline in the past and their changes with time. The geographic information system (GIS) helps in storing, updating and effectively using the existing data on the development of estuarine areas. This method allows studying extensive territories, identifying consistently, objectively and comprehensively the current status of the coastline in this estuarine area at the time of compilation of the topographic map as well as the time of taking the air photos and satellite images.

\section{Procedures:}

Image registration: This step is to correct the error in coordinates during acquisition phase. Landsat 8 LGN acquired in 7/2016 was calibrated using topographic map at scale of 1:10,000 issued by Department of Cartography - Ministry of Natural Resources and Environment in 2000. Landsat scenes in 1979, 1990, 2000, 2010 were calibrated using Landsat 8. Topographic maps of the studied area (Cua Viet) in 1965 with scale 1:50,000, were digitized and geo-referenced to aerial photo acquired in 1952. Images and maps were projected in UTM Zone 48, WGS84. Only images with error less than 1 pixel after image registration were selected. If the errors are greater than 1, the Ground Control Points (GCP) will be re-selected until the requirement is met.

\section{Image enhancement:}

Image enhancement is the transformation of original image into a new one in order to make image clearer and more interpretative. Image after enhancement helps the visual interpretation or computer processing more effective and accurate. Digital values of satellite channels often range in a narrow band comparing to the display capability of the image (an 8-bit image has 256 display values), each band tends to be too dark or too bright when displaying. Therefore, enhancing the contrast for images is implemented by stretching image values.

Enhancing contrast is to highlight the important objects to make it easier to interpret than in the original image. Depend on the specific applications, remotely sensed image, band characteristics, the specialist adjusts the brightness and contrast level [4].

Digitization: Semi-automatically digitize the coastline in remotely sensed images of 1979, 1990, 2000, 2010 and 2015, then overlay the coastline maps which were digitized from aerial photos and topographic maps in 1965 to assess the process of the coastal lines in the Cua Viet outlet area. To make the semiautomatic process accurate, we adopted the method by Claire, (2012), the coastline was highlighted using NDWI (Normalized Difference Water Index) as in the formula:

$$
N D W I=\frac{B_{4}-B_{5}}{B_{4}+B_{5}}
$$

NDWI allows discrimination of soil and water (Claire, (2012)). We then used rationing to highlight the coastline:

$$
\text { coastline }=\frac{B_{4}-B_{5}}{B_{4}+B_{5}}
$$

Where: Band 2 ranges from $0.52-0.6 \mu \mathrm{m}$; Band 4 ranges from $0.76-0.9 \mu \mathrm{m}$; Band 5 ranges from $1.55-1.75 \mu \mathrm{m}$. 
The result from above steps is the coastline in raster format. After that, data were processed in GIS environment to digitize semiautomatically and complete the coastline map.

\section{Calibration of tide [5]:}

The accuracy of coastline in the image depends on the tidal height at the time of image acquisition. The height of tide at acquisition time can be estimated as follows:

$$
y=\frac{H_{\max }+H_{\min }}{2} \pm \frac{H_{\max }-H_{\min }}{2} \cos \frac{\pi \Delta t}{\Delta T}
$$

Where: $y$ : the tidal height; $t$ : time of image acquisition; $H_{\max }$ : the height of the high tide; $H_{\min }$ : the height of low tide; $\Delta T$ : the time interval between the low and the high tide; $\Delta t$ : the time interval between the preceding event (high or low tide).

The negative sign that happens before acquisition time indicates low tide.

After estimating tidal height, we use Digital Elevation Model extracted from global ASTER (http://www.jspacesystems.or.jp/ersdac/GDEM /E/4.html), national height mark and topographic maps of studied area at 1:10,000 scale which were established by Institute of Geography - Vietnam Academy of Science of Technology in 2006 and 2007, to delineate the coastline from satellite image.

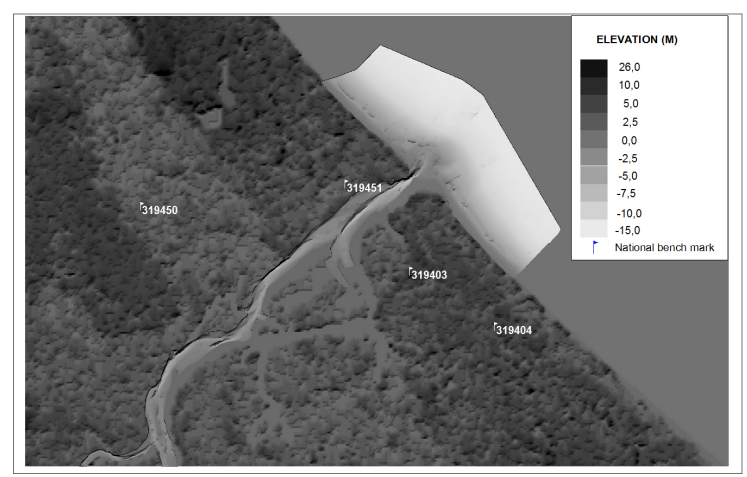

Fig. 5. Digital Elevation Model of studied area

\section{RESULTS OF INTERPRETATION}

Based on the results of processing and interpretation of the coastline from maps, air photos, satellite images and the results of survey by the Institute of Geography from 2002 to 2008 [6] the authors of this paper have a map of coastline development of Cua Viet outlet area in the period 1952 - 2015 (fig. 6). Analysis of the status of river bank and coastline over various periods in 1952, 1965, 1979, 1990, 2000, 2010 and 2015 and related data has allowed setting forth some important remarks on the coastline development in Cua Viet outlet area.

The river from Gia Do confluence (the confluence between the Hieu river and the Thach Han river) to Cua Viet outlet has a length of $13.5 \mathrm{~km}$. This is the final reach of the Thach Han river flowing on the coastal plain. It flows in SW-NE direction. Before discharging to the sea at Cua Viet outlet, the Thach Han river receives an inflow of water on the left side from Vinh Dinh river which meets with it at $\mathrm{An} \mathrm{Cu}$ and Tuong Van. The low land downstream area of Thach Han river is indeed a liman which is in the process of being filled up, with a very highly developed hydrographic system [1].

Similar to many other estuarine areas in the Central region, in the Cua Viet coastal area, there are sand dunes parallel with the coastline. The river system has divided its estuarine area into several large flood plains such as those in Gia Do, Qui Ha, Tuong Van, Mai Thi communes and many low flood plains developed in the form of "drifting sand islands" in the river channel [7] (fig. 6).

To evaluate in detail the specific coastal sections, the authors have divided the coast in this area into 3 sections: the one inside and two outside the Cua Viet outlet. These coast sections have the following development characteristics.

\section{Cua Viet outlet section}

This section has intensive changes due to economic activities of humans in recent years. Many river reaches have been blocked and filled up, many tracts of lowland in the river mouth area have been developed for rice cultivation and aquaculture. Human activities have caused the artificial erosion-accretion in the lowland of Cua Viet outlet area. 
Evaluation of coastline development over ...

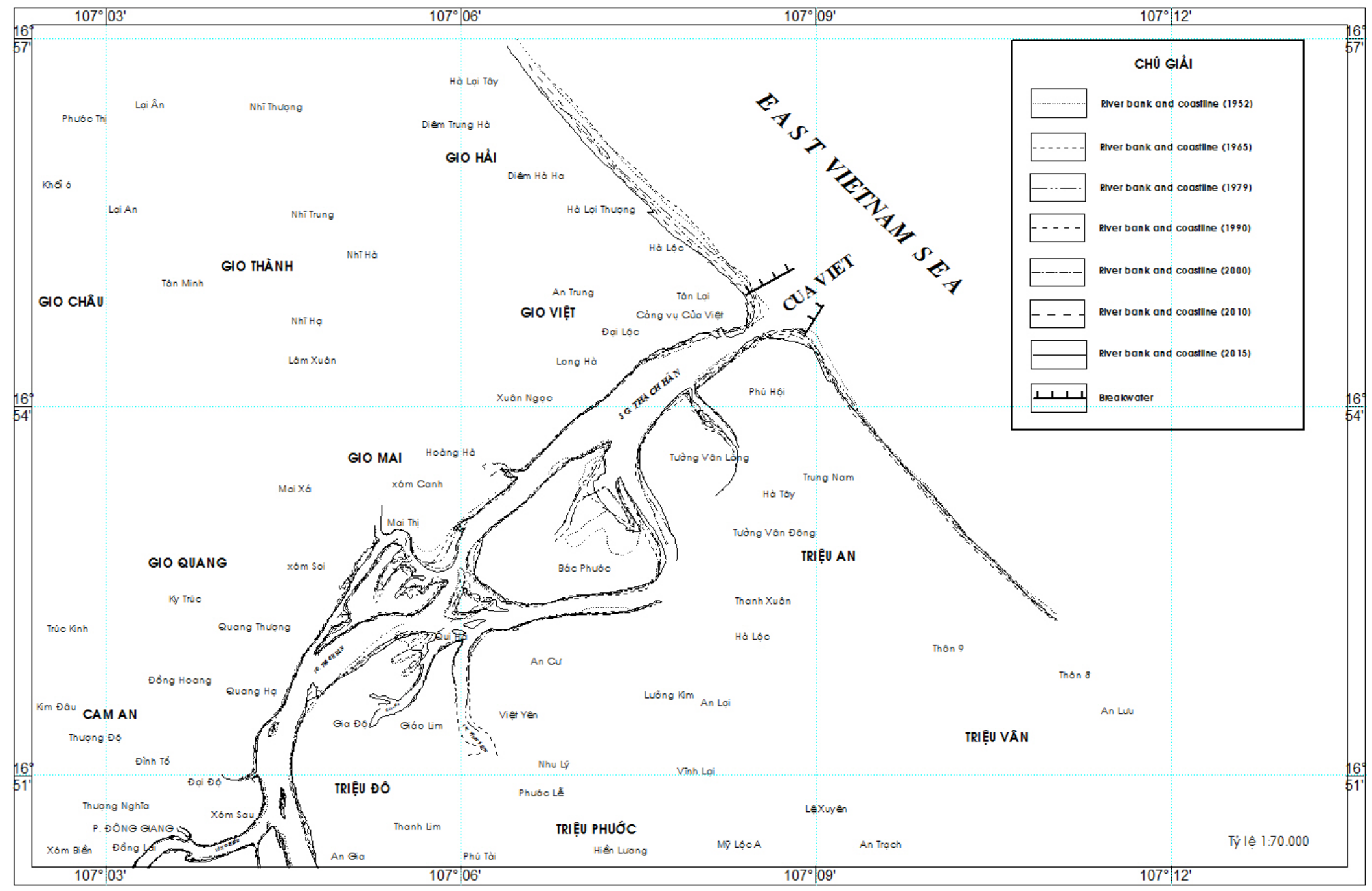

Fig. 6. Map of coastline changes in Cua Viet outlet area in the period 1952 - 2015 
Natural erosion-accretion occurs alternately in most of meandered and straight reaches of the river. Compared with the upstream reaches, the lateral erosion in Cua Viet outlet area is larger in extent and stronger in intensity. The most notable area is the left side of the bank (Dai Loc village) where for the last 30 years lateral erosion has been in average of $4.0 \mathrm{~m} /$ year [7]. In Long $\mathrm{Ha}$ area there is a gradual shift of the mainstream flow direction to the north. On the southern bank of the reach at Phu Hoi, erosion has been occurring frequently over many years but with a low intensity. The further inland, the stronger the erosion of the Thach Han river bank. Most of the bank here is protected by embankment, but erosion still occurs, affecting the production as well as the life of the local people; typically, in October 2013, storms number 10 and 11 broke the northern part of Cua Viet seawall, $3.5 \mathrm{~km}$ of the seawall from Gio Viet to Cua Viet was severely destroyed (see fig. 6 and tab. 1).

Table 1. Development of river bank erosion-accretion in the reach from Gia Do confluence to Cua Viet outlet in period 1952 - 2015

\begin{tabular}{|c|c|c|c|c|c|c|c|}
\hline & From & To 1965 & To 1979 & To 1990 & To 2000 & To 2010 & To 2015 \\
\hline$\overline{\text { Average accretion rate (m/year) }}$ & \multirow{4}{*}{1952} & +1.14 & +1.63 & +1.72 & +1.69 & +1.66 & +1.53 \\
\hline Average erosion rate (m/year) & & -2.25 & -1.89 & -1.89 & -1.91 & -1.58 & -1.69 \\
\hline Accretion area $\left(\mathrm{m}^{2}\right)$ & & $+43,376$ & $+110,918$ & $+220,738$ & $+426,482$ & $+233,022$ & $+107,386$ \\
\hline Erosion area $\left(\mathrm{m}^{2}\right)$ & & $-80,244$ & $-130,430$ & $-255,292$ & $-510,228$ & $-322,780$ & $-172,626$ \\
\hline Average accretion rate (m/year) & \multirow{4}{*}{1965} & & +2.12 & +1.80 & +1.66 & +1.57 & +1.49 \\
\hline Average erosion rate (m/year) & & & -1.52 & -1.89 & -1.92 & -1.90 & -1.95 \\
\hline Accretion area $\left(\mathrm{m}^{2}\right)$ & & & $+67,542$ & $+109,820$ & $+205,744$ & $+381,494$ & $+181,875$ \\
\hline Erosion area $\left(\mathrm{m}^{2}\right)$ & & & $-50,186$ & $-124,862$ & $-254,936$ & $-502,684$ & $-257,956$ \\
\hline Average accretion rate (m/year) & \multirow{4}{*}{1979} & & & +1.48 & +1.52 & +1.49 & +1.56 \\
\hline Average erosion rate (m/year) & & & & -2.25 & -1.95 & -1.88 & -1.82 \\
\hline Accretion area $\left(\mathrm{m}^{2}\right)$ & & & & $+42,278$ & $+95,924$ & $+175,750$ & $+89,532$ \\
\hline Erosion area $\left(\mathrm{m}^{2}\right)$ & & & & $-74,676$ & $-130,074$ & $-247,748$ & $-118,658$ \\
\hline Average accretion rate (m/year) & \multirow{4}{*}{1990} & & & & +1.56 & +1.46 & +1.42 \\
\hline Average erosion rate (m/year) & & & & & -1.65 & -1.80 & -1.91 \\
\hline Accretion area $\left(\mathrm{m}^{2}\right)$ & & & & & $+53,646$ & $+79,826$ & $+38,819$ \\
\hline Erosion area $\left(\mathrm{m}^{2}\right)$ & & & & & $-55,398$ & $-117,674$ & $-62,432$ \\
\hline Average accretion rate (m/year) & \multirow{4}{*}{2000} & & & & & +1.35 & +1.32 \\
\hline Average erosion rate (m/year) & & & & & & -1.95 & -1.98 \\
\hline Accretion area $\left(\mathrm{m}^{2}\right)$ & & & & & & $+26,180$ & $+12,799$ \\
\hline Erosion area $\left(\mathrm{m}^{2}\right)$ & & & & & & $-62,276$ & $-31,617$ \\
\hline Average accretion rate (m/year) & \multirow{4}{*}{2010} & & & & & & +1.28 \\
\hline Average erosion rate (m/year) & & & & & & & -1.86 \\
\hline Accretion area $\left(\mathrm{m}^{2}\right)$ & & & & & & & $+11,486$ \\
\hline Erosion area $\left(\mathrm{m}^{2}\right)$ & & & & & & & $-29,700$ \\
\hline
\end{tabular}

Notes: (+) is for accretion; (-) is for erosion.

\section{Sections outside the Cua Viet outlet}

The changes outside the Cua Viet outlet occur due to not only the actions of the flood water but also marine dynamic factors (wave, wind, tide, coastal current, sea level rise ...). Due to the straight configuration with unconsolidated sandy sediments easily eroded by the action of waves and coastal currents, the coast outside the Cua Viet outlet changes strongly by seasons. Similar to many other river mouths in the Central region, the river mouth here narrows in the low water season and expands in the flood season. Especially during the historic flood in November 1999 the Cua Viet outlet experienced a drastic change as the low sand bars on both sides of the river mouth were destroyed by high flood [1].

Over the last nearly 60 years coastal erosion has occurred on both sides of the outlet, with the following trends and characteristics (tab. 2): 
North section of Cua Viet outlet: Before 1965, the coast tended to accrete seawards, but after 1965 erosion has occurred strongly throughout the coast section adjacent to the outlet. The lateral erosion rate reached $5 \div$ $6 \mathrm{~m} /$ year. By 2015, the coastline has retreated inland $164 \mathrm{~m}$ from its position in 1952. Since 1980, when the Tram dam - the largest hydraulic engineering work across Thach Han river - was put into operation, the coastal erosion has been occurring with ever increasing rate [7].

South section of Cua Viet outlet: The erosion in this coastal section occurs at lower rate, about $2.0 \mathrm{~m} /$ year on average. Due to the action of flood current appearing every year as well as that of marine dynamic factors (wave, long-shore currents and tide) occurring in typical seasons, the sand bars here change frequently, sometimes are accreted and significantly eroded.

Recently, thanks to the completion of Hung Vuong bridge and Cua Viet seawall on both sides of the river mouth, the process of coastal erosion tends to reduce, and the seawall has started to consolidate (fig. 6 and tab. 2).

Table 2. Development of erosion - accretion on the coast outside Cua Viet outlet in period 1952 - 2015

\begin{tabular}{|c|c|c|c|c|c|c|c|}
\hline & From & To 1965 & To 1979 & To 1990 & To 2000 & To 2010 & To 2015 \\
\hline Average accretion rate (m/year) & \multirow{4}{*}{1952} & +2.41 & +1.26 & +0.72 & +0.50 & +0.44 & +0.56 \\
\hline Average erosion rate (m/year) & & -2.79 & -4.01 & -5.36 & -6.35 & -4.85 & -4.25 \\
\hline Accretion area $\left(\mathrm{m}^{2}\right)$ & & $+11,164$ & $+12,889$ & $+17,569$ & $+28,438$ & $+25,588$ & $+16,238$ \\
\hline Erosion area $\left(\mathrm{m}^{2}\right)$ & & $-9,526$ & $-202,401$ & $-699,952$ & $-1,777,964$ & $-990,574$ & $-434,014$ \\
\hline Average accretion rate (m/year) & \multirow{4}{*}{1965} & & +0.12 & +0.17 & +0.28 & +0.49 & +0.58 \\
\hline Average erosion rate (m/year) & & & -5.20 & -6.76 & -7.34 & -7.23 & -7.04 \\
\hline Accretion area $\left(\mathrm{m}^{2}\right)$ & & & $+1,725$ & $+4,680$ & $+10,869$ & $+20,943$ & $+12,349$ \\
\hline Erosion area $\left(\mathrm{m}^{2}\right)$ & & & $-192,875$ & $-497,551$ & $-1,078,012$ & $-2,101,970$ & $-1,023,366$ \\
\hline Average accretion rate (m/year) & \multirow{4}{*}{1979} & & & +0.22 & +0.39 & +0.70 & +0.78 \\
\hline Average erosion rate (m/year) & & & & -8.25 & -7.95 & -7.13 & -6.45 \\
\hline Accretion area $\left(\mathrm{m}^{2}\right)$ & & & & $+2,955$ & $+6,189$ & $+10,074$ & $+11,255$ \\
\hline Erosion area $\left(\mathrm{m}^{2}\right)$ & & & & $-304,676$ & $-580,461$ & $-1,023,958$ & $-463,151$ \\
\hline Average accretion rate (m/year) & \multirow{4}{*}{1990} & & & & +0.56 & +1.01 & +1.12 \\
\hline Average erosion rate (m/year) & & & & & -7.65 & -6.3 & -5.4 \\
\hline Accretion area $\left(\mathrm{m}^{2}\right)$ & & & & & $+3,234$ & $+3,885$ & $+14,568$ \\
\hline Erosion area $\left(\mathrm{m}^{2}\right)$ & & & & & $-275,785$ & $-443,497$ & $-36,256$ \\
\hline Average accretion rate (m/year) & \multirow{4}{*}{2000} & & & & & +1.45 & +1.65 \\
\hline Average erosion rate (m/year) & & & & & & -4.95 & -4.62 \\
\hline Accretion area $\left(\mathrm{m}^{2}\right)$ & & & & & & +651 & $+1,122$ \\
\hline Erosion area $\left(\mathrm{m}^{2}\right)$ & & & & & & $-167,712$ & $-88,925$ \\
\hline Average accretion rate (m/year) & \multirow{4}{*}{2010} & & & & & & +1.82 \\
\hline Average erosion rate (m/year) & & & & & & & -3.53 \\
\hline Accretion area $\left(\mathrm{m}^{2}\right)$ & & & & & & & +965 \\
\hline Erosion area $\left(\mathrm{m}^{2}\right)$ & & & & & & & $-42,317$ \\
\hline
\end{tabular}

Notes: (+) is for accretion; (-) is for erosion.

Thus, erosion has been occurring throughout a long period on the left bank of Thach Han river, in the coast section inside and outside Cua Viet outlet, causing great impacts on the population here and the waterway transport to and from the Cua Viet outlet.

\section{CONCLUSION REMARKS}

This paper has presented a modern method applicable for studying the changes of the coastlines and river mouths and its application to reproduce the development of the coastline in the Cua Viet outlet area through various periods from 1952 to 2015 with the use of remote sensing data and GIS. This is an effective method for evaluating the status and 
development of coastlines and river mouths. It allows studying consistently and objectively in extensive areas the status of coastline at present as well as at various moments in the past. The quantitative evaluation of the coastal and river mouth accretion-erosion processes can serve as the basis for proposing measures for preventing and controlling erosion, protecting and stabilizing the coastlines and river mouths effectively to serve the marine economic development in the area.

The results of study show that inside the Cua Viet outlet natural erosion - accretion processes occur alternatively in most of curved and some straight river reaches. The most notable area is the northern bank (in Dai Loc village) where erosion has been occurring strongly for the last 30 years with average rate up to $4 \mathrm{~m} /$ year. On the southern bank at Phu Hoi, erosion has been occurring frequently for many years but with low intensity.

Outside the Cua Viet outlet, during nearly 65 years, coastal erosion has occurred in both the northern and the southern coastal sections, but with different extent and characteristics: In the northern section, the lateral erosion rate reaches $5 \div 6 \mathrm{~m} /$ year; in the southern section the average erosion rate is $2.0 \mathrm{~m} /$ year.

The results of this study are of significant to serve the management, planning and exploitation of natural resources for economic development, disaster control and environmental protection. To predict exactly the development of the coastline, studies must be carried out by a combination of various methods.

The extracted shoreline from remotely sensed data was semi-automatically created by combining the automatically processed algorithm and the semi-automatically calibrated tide procedure. Therefore, it is clear that the accuracy of the research and also the calibrated tide procedure will be affected by the semiautomatic process. However, this issue can be solved by using multi-temporal remotely sensed imagery in a year to find out the sphere's influence of beach tide and extract out the optimal shoreline from LANDSAT imagery.

\section{REFERENCES}

1. Dao Dinh Cham, 2012. Research on the development of the Cua Viet estuary, Quang Tri province, to serve flood discharge and waterway transport. Doctor Thesis on Geography. Institute of Geography, Vietnam Academy of Science and Technology, Hanoi. 136 p. (In Vietnamese).

2. Manual of meteorological and hydrological characteristics of continental shelf areas of Vietnam, 2000. General Department of Meteorology and Hydrology, Center for Marine Meteorology and Hydrology. Agriculture Publishing House, Hanoi. 58 pp. (In Vietnamese)

3. Alesheikh, A. A., Ghorbanali, A., and Nouri, N., 2007. Coastline change detection using remote sensing. International Journal of Environmental Science and Technology, 4(1): 61-66.

4. Gao, B. C., 1996. NDWI-A normalized difference water index for remote sensing of vegetation liquid water from space. Remote Sensing of Environment, 58(3): 257-266.

5. Gonçalves, G., Duro, N., Sousa, E., Pinto, L., and Figueiredo, I., 2014. Detecting changes on coastal primary sand dunes using multi-temporal Landsat Imagery. In SPIE Remote Sensing (pp. 924420924420). International Society for Optics and Photonics.

6. Thieler, E. R., Martin, D., and Ergul, A., 2003. The digital shoreline analysis system, version 2.0: shoreline change measurement software extension for Arcview. US Geological Survey Open-File Report, 3, 076.

7. Nguyen Thanh, Tran Huu Tuyen, 1997. Impacts of human activities on the geoenvironment in the downstream areas of major rivers in Binh Tri Thien region. Proceedings of the $13^{\text {th }}$ Science Conference of Hanoi University of Mining and Geology, pp. 99-103. 


\title{
ÚNG DUỦ G CÔNG NGHẸ VIỄN THÁM VÀ HỆ THÔNG TIN ĐỊA LÝ (GIS) TRONG ĐÁNH GIÁ DIỄN BIẾN ĐƯỜNG BỜ VƯNG CỬA SÔNG CƯA VIẸTT QUA CÁC THỜI KỲ
}

\author{
Đào Đình Châm, Nguyễn Thái Sơn
}

Viện Địa lý-Viện Hàn lâm Khoa học và Công nghệ Việt Nam

\begin{abstract}
TÓM TÄT: Quá trình diễn biến đương bờ vùng cưa sông Cưa Việt tù̀ năm 1952 đến năm 2015 được đánh giá định lương bằng công nghệ viễn thám và hệ thông tin địa lý (GIS). Kết quả nghiên cứu cho thấy, ở vùng cứa sông ven biển Cưa Việt, hiện tuợng bồi - xói xảy ra rất phức tạp, hoạt động xói lở đường bờ chiếm ưu thế hơn so với hoạt động bồi tụ cả về qui mô lẫn cuờng độ, trong đó các đoạn bờ có qui mô và cường độ xói lở mạnh nhất thường phân bố ở gần cửa sông (cả ở phía trong và phía ngoài của sông). Đoạn bò phía trong cưa sông, phía bò̀ bắc xói lở xảy ra mạnh hơn phía bò̀ nam, tốc độ xói đạt tù $-1,51 \div-2,24 \mathrm{~m} / \mathrm{năm}$, tốc độ bồi có giá trị tù $1,15 \div 1,70 \mathrm{~m} / \mathrm{năm}$. Tỷ lệ

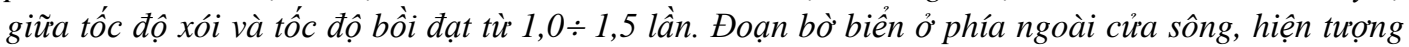
xói lở xảy ra mạnh hơn nhiều, với tốc độ xói tù $-2,74 \div-8,18 \mathrm{~m} / \mathrm{năm}$, tốc độ bồi chỉ đạt tù $0,12 \div$ $2,41 \mathrm{~m} / \mathrm{năm}$, tỷ lẹ giữa tốc độ xói và tốc độ bồi đạt tù 1,0 $\div 38$ lần. Gần đây, kè biển Cửa Việt được xây dụng đã khắc phuc được một phần nào về quá trình xói lở bờ biển, bãi biển đã có sư bồi tu ở khu vục chân kè.
\end{abstract}

Tù khóa: Công nghệ viễn thám, hệ thông tin địa lý, đường bò̀ biển, của sông, Của Việt. 